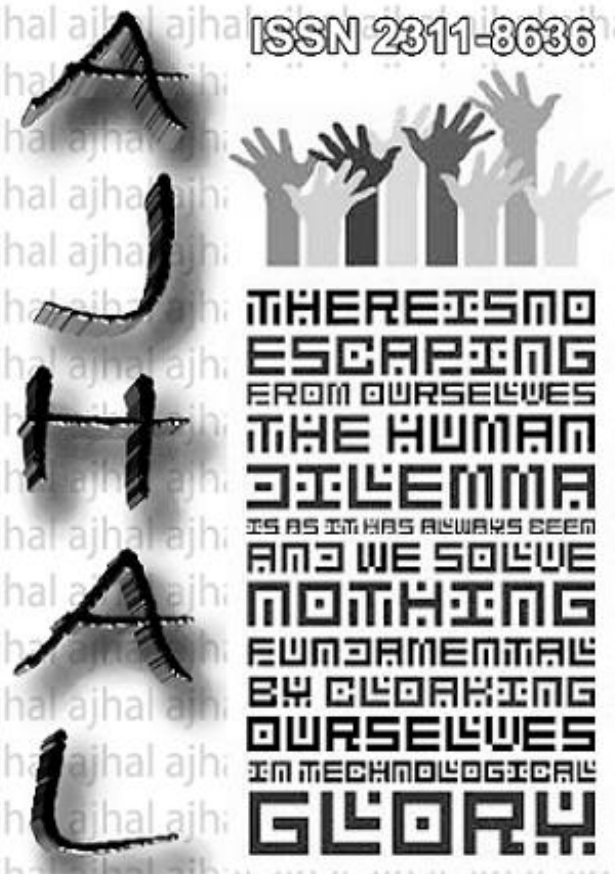

Vol 3, No. 1/2016

Asjan Jourmal of Humanity, Art and Litergatulue 


\title{
Being Brown: The Inconvenient Truth
}

\section{Ma. Raiza Ledesma}

School of Humanities, University of Asia and the Pacific, PHILIPPINES

ISSN: 2311-8636 (Print)
ISSN: 2312-2021 (Online)

Volume 3, Number 1/2016

DOI prefix: 10.18034/ajhal

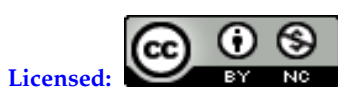

Source of Support: Nil

Conflict of Interest: None Declared

Email for correspondence: raiza.ledesma@vahoo.com

\begin{abstract}
This is an analysis to a Carlos Palanca Memorial Awards winner short story entitled Sunburn by Gilda CorderoFernando. It tackles themes such as racial discrimination, inequality and assimilation.
\end{abstract}

Key Words: Filipinos, Racial Discrimination, Assimilation, Inequality

\section{INTRODUCTION}

On the surface, it would be quite simple to peg Gilda Cordero-Fernando's short story entitled Sunburn as a straightforward story about racial inequalities in PostWar America. However, doing that would be a disservice to the complexities offered with the lines of her text. Outwardly, Cordero-Fernando's Sunburn is a characterdriven story about three Filipinos chasing their conceived versions of the American Dream, in the way they know how. And essentially, it is a story of struggling with assimilation; the failure to grow and the limitations that inhibit said growth provided by external factors as Filipinos living in the global world. To these points, this paper will discuss Sunburn as both a literature piece and social commentary. as well as, seek to discern its strengths and weaknesses in these respects.

\section{Sunburn: The Narrative and Message}

The story begins with the introduction of Rodrigo M. Magnum, a loud and rambunctious Filipino man, with whom the narrator of the story, an unnamed Filipina is with, on a boat set for sail to America. Magnum is described as a "blustery fellow with a chest thrown out to the winds" (Cordero-Fernando, 55). The story continues by describing Magnum in detail, in that he was an ordinary Filipino with an overbearing and obnoxious personality, complete with exaggerated traits and manner of dress. He and the narrator are slated to continue their education in the United States.

While traveling on the boat, the narrator divulges more about Magnum's personality and how the foreigners on board are fascinated and amused by Magnum's stories but reveal that there are preconceived notions they have towards Filipinos and seemingly assume that all Filipino men and women are similar to him. One of the waiters on the boat expressed disdain when Magnum failed to show up in the dining room due to seasickness: "After all, what can you expect from an Oriental?" (Cordero-Fernando, 56) 
The narrator goes on to describe how the American women took advantage of the sunny weather on the boat and dressed in skimpy attire to get tanned, as opposed to her, who was in quarter sleeves and stayed under the shade:

Long-legged, the American women lolled about in their shorts and halter tops, rubbing suntan lotion on each others' shoulders. They spread bright beach towels on the edge of the pool and sunbathed there for hours... I wore three-quarter sleeves and stayed under the shady awnings. (Cordero-Fernando, 56)

Here we see the author trying to use clear and topical ways that Filipinos in the story differ from their caucasian and American counterparts. The narrator then lists the different seemingly ignorant questions the foreigners had for both of them Filipinos:

'And is the Philippines still full of palm trees and girls in grass skirts?' asked my neighbor on the left over a Bertha Clay novel. 'My life's dream has always been to buy one of your islands,' chimed in her husband, 'And life there a life of tropical splendor.' (Cordero-Fernando, 56)

Not only does this reveal that the foreigners, though well meaning, were quite ignorant about the Philippines and Filipino culture, but it reveals the stark difference between the narrator and Magnum. After having been asked the questions, on the one hand, Magnum was quite excited to humor and answer the Americans' condescending questions. While the narrator, on the other hand, had grown tired of the conversation, answered sarcastically when asked where she lived, "In the highest coconut tree,' I answered" (Cordero-Fernando, 56).

The readers are, then, revealed the nature of the education Magnum and the narrator will be receiving in the United States. The narrator would be taking up an entire course on Literature, while Magnum could only afford Mambo dancing lessons, as he pawned what was presumably his tuition money for a Buick convertible. Here we see more of Magnum's character and what he values, as well as where his priorities lie, in "Propagandizing the Philippines" without actually going to school and trading that in to look flashy with a new car. The story progresses and we are, then, introduced to Noli, with whom the narrator had been paired up with, as he was a Filipino upperclassman who had been there two years prior. The narrator further describes her university life and how she is assimilating. Assimilation is one of the main themes of this short story. With the proper guidance of Noli, the narrator is able to assimilate quite well with her foreign peers. During the acquaintance party set up by their dean, the narrator meets Billie and Nathan, a newlywed American couple and is with several other foreigners, Pilar the Spanish girl from Barcelona, Otto who is presumably German, Rajendra, an Indian, Darryl, the Australian and the Taiwanese Chai. The author, then, recounts Magnum trying to teach a reluctant Mexican girl what he had learned in mambo class. Here, the author is trying to describe what sets Filipinos apart. Aside from outward appearances in clothing and skin, language is something that differentiates Filipinos, in that, the grammar that well-educated Filipinos have is "straight from the grammar texts" (Cordero-Fernando, 58).

Thus far, in the story, the readers are met, once again, by Noli. His quiet demeanor is a stark contrast to that of Magnum's. The author's attempt to not only compare the narrator to Magnum is further strengthened because of their differing demeanors but it also highlights two kinds of Filipinos, which is the story's main thrust. For example, when Charlie says, "'Do you know,' Charlie told me, 'that Noli is the only foreigner I know who speaks English without an accent?' Noli beamed. He liked it alright. It tickled him pink to be told he spoke English like a native" (Cordero-Fernando, 58). It is quite interesting to see how Noli was incredibly proud that he had shed off his "Filipino-ness" and that he 
assimilated and was called "almost an American" (Cordero-Fernando, 58) by an actual American. It is in this we see Magnum, on the one hand, yelling Filipino expletives, his attempt to "propagandize the Philippines", and then we have Noli, on the other, who is extremely proud to have assimilated and could even be mistaken for Americans by Americans.

This reverse patriotism continues in the story when the narrator goes on to describe that Noli is no longer a Filipino because he has been around the globe:

You, Noli, are not the Filipino with your dirty Oxford shoes and your American accent. You've spent a year studying the arts in Paris and gone through most of Europe. You major in Russian Literature and you're very proud of your French. As you lie on your bed at night, you dream of beer gardens of Hamburg and sleepily strum a Hawaiian guitar. You do not carry the scars of Bataan on your ankles. You are rather vain about your fair complexion and the tall nose inherited from a Castillan grandfather. (Cordero-Fernando, 59)

Whereas, Magnum, according to the author, is the quintessential Filipino, with no other way to describe him than to call him Filipino: "Magnum is the Filipino with his mambo and his calling cards and his flashy car, the way he swaggers down the street as if he owned it" (Cordero-Fernando, 59).

This second hand shame is a rather problematic theme that the narrator and the author are quite conflicted in. There is a sense of pride that the author writes with when she and Noli are projected as the better kind of Filipino. Using Magnum to contrast their shame in Filipinos by simply being who he is can be quite reductive. One can easily fall into the trap of being on the side of the narrator and Noli, but one perspective to consider is that in the story Noli is clearly and exaggeratingly demonized to glorify the apparent Colonial Mentality. Whether or not this was one purpose is subject matter for another discourse. Suffice it to say, there is an argument to be said for both Magnum's and Noli's personas.

In the next part of the story, the narrator recounts the three Filipinos undergoing something uncommon for Filipinos to experience: cold weather. Noli and the narrator would remain indoors, keeping warm while Magnum was set to prove to the Americans that Filipinos could survive in cold weather. Magnum's reckless behavior was then revealed to have led him to a suspension. While the story continues, the strength in Magnum's conviction, his arrogance towards authority, and the nonchalance he feels towards foreigners becomes clear to the readers that it will ultimately result to his eventual downfall.

In a car ride with the American couple Billie and Nathan, the narrator, Noli and Magnum discuss tanning and how Filipinas would never try to catch some rays with the hope to get dark, just as the narrator had worn a three-fourth sleeved shirt and remained under the shade while the American women were in their skimpiest apparel, hoping to get tanned skin. Magnum goes on and tells an old wive's tale about how Filipinos were made, in another attempt at propagandizing the Philippines. Magnum comes across off, once again, as obnoxious, without intending to do so.

Later on, Noli asks Nathan why he was being so nice to the Filipinos. He told the story of a Japanese national who did a good deed towards him and the narrator reflects on his anecdote. She resolves to "do something nice for the first foreigner" (Cordero-Fernando, 61) she meets. This is quite ironic that she would be willing to start a "chain of friendship around the world" while simultaneously and self-righteously reducing Filipinos like Magnum to the level of the hopelessly uneducated and ignorant. 
The story progresses and Noli has no kind words left for Magnum: "Every time Noli came, he had a new tale of something that infuriated him about Magnum" (Cordero-Fernando, 62). Again, the readers are shown the continuous manner in which Magnum is put down. Magnum is clearly written off as a nuisance and a Filipino no one wanted to associate with. While the Americanized Filipinos, that is, Noli and the narrator, were off enjoying their newfound culture and find respite without Magnum, we learn that Magnum has gone back to the Philippines together with the Buick he had loaned. As the couple shared their disdain with one another, there was a hint of expected disappointment expressed in the dialogue between the narrator and Noli. They blamed Magnum for the bad reputation and perception foreigners had for Filipinos. While their disdain is rooted in something concrete, in that Magnum did have a tendency to overdo the Filipino propagandizing, and he was, by all means, irritating, there is an obvious need for something to be said about how Noli and the narrator were so quick to write him off as someone beneath them. To this point, it is clear in Magnum's return to the Philippines that Noli and the narrator were free to experience and fully realize their ambitions to live the American dream.

The two are then married and are on the quest to find an apartment. They had found the perfect apartment they had wanted to live in:

The next week we decided to rent an apartment in Peachtree Corners. Noli arranged everything by telephone and by mail, including the sending of the advance rent. No more shared bath, no more closet-kitchen, no garbage to lower. Peeping from pale pink wistoria blossoms, its deep windows looked out on a residential street with babies sunning in their prams. (Cordero-Fernando, 63)

The two then proceeded to Peachtree corners and discovered that they would be rejected as occupants in the apartment. The agent, Mr. Isaacs, and Noli had done all of the transactions over the phone, and because Noli had an American accent, it had not occurred to the agent that he was not caucasian by ethnicity. A very poignant passage in the story, Noli and the narrator had been told off because of their race:

'You see, we did all our transactions by telephone... I didn't know... I didn't realize... you see, the neighbors are rather... I mean the owners have a policy...' He threw up his long arms. 'My God, I'm only an agent. You can talk to the owners in Manhattan, I will give you their address.' His hooked nose pointed towards the window like a weathervane, to indicate that our interview was over. (Cordero-Fernando, 63)

Indicative of more traditional and conservative Americans at the time, shortly after the Japanese occupation, that is, the 1950s and early 1960s, this incident shows that regardless of how superior Noli and the narrator felt previously; the Filipino and the superiority they felt towards Magnum was irrelevant to the outside world.

Noli and the narrator had been returned their initial deposit for their rent. The narrator reflects on the cold reception they had been afforded by the agent. The disbelief in her tone is indicative of shock and surprise:

Noli and I had finished five years of college. We came from respectable hardworking families who sent us our allowance with religious regularity. We spoke good English, we bathed everyday, had impeccable table manners and a reasonable amount of interesting conversation. Yet past the International Date Line, we were brown, they were white, as irrevocably as if the tropic sun followed us everywhere to give us a sunburn.

Homeless and dejected, the narrator ends the short story with a reflection that perhaps, the American Dream that they were chasing was not completely idyllic, as they had imagined, 
confined within the walls of their diverse university. The narrator then recalls the words she had memorized upon reaching the US shores, Lady Liberty's words, and reflecting on the irony that they were thrust upon.

As a piece of literature, Cordero-Fernando's Sunburn is not obvious in its writing style, as there were a number of deductions the readers must make, such as the gender of the narrator and the intentions of Noli toward the narrator. It was one of those stories that require multiple readings to fully grasp the humor and the narrative style, as many of the events mentioned in the story were disjointed and would jump to and fro various timelines in its exposition. For example, the author had not explicitly and overtly said that the story spanned for over five years. In between those years spent in the US, the readers would have to fill in the blanks to understand what kind of university life Noli and the narrator had gone through, which might have been helpful to strengthen the main theme Filipino assimilation in the supposed "Land of the Free.

Briefly discussed previously were the prominent symbolisms that run through Sunburn's text, such as Magnum representing the average Filipino, loud and obnoxious, Noli, the traveled, educated Filipino exposed to the ways of the world, and the narrator, a sponge and foil to Noli's ways, with the desire to acquire Noli's knowledge. Although this was clear in the narrative, the purpose of these characters had not been clearly revealed. It had been missing from beginning to end. It was problematic, in that the characters had been reactive and passive in their circumstances: Magnum reacting to external forces because of his stubborn character, Noli reacting to Magnum and then the landlord, and the narrator merely mirroring and following Noli's growth. The character development, as a result, failed to hit the mark, as there was no clear indication for any growth until the very end, wherein the narrator reflected on the rejection they had just faced of being in a supposedly diverse country, free from discrimination. Now, whether or not the characters changed their behavior as a result of this circumstance remains inconclusive.

To this point, the ending was not as strong as it should have been. It might and could have been stronger had Magnum still been in the picture. If he had remained, with all his bravado and was able to acquire an apartment or help Noli and the narrator in their time of trouble, in spite of his obvious shortcomings, it might have created a less anti-climactic ending for our main protagonists. It would have better rounded out the story. Perhaps, the protagonists could realize that Magnum, in spite of his shortcomings was still a brother. They could put him down in their internal conversations but the real spirit of Filipino pride would have come through.

The main message conveyed within the lines of the story was that of Philippine identity in progress. The troublesome Filipino identity, thrust upon the global context had not been fully realized, and in the story, three Filipinos were trying to establish themselves in the global context without even knowing fully well in themselves what about themselves, inherently Filipino, there was to be proud of. With Magnum as the exception, Noli and the narrator were proud of assimilating without any reminders of who they were as Filipinos. This was problematic and seemingly done on purpose. It was as if the author had written these characters with the idea that one would hold the right ideologies but would not know how to express them, in Magnum, while the other two would have been equipped with the right temperament and educational attainment but did not have anything substantial to offer to the world, except for ideologies picked up from other cultures.

While the storytelling and narrative techniques had some apparent flaws, the irony that came with the story was what gave the story its strength. The fact that Noli and Magnum were juxtaposed in a way that they would ultimately clash and give light to the educated 
Filipino versus the uneducated Filipino, in that Noli would have something untoward to say about Magnum and in the end, the superiority of Noli was unfounded because of the trappings of racial inequality moved the story forward.

Aside from these, a number of things can be said about Gilda Cordero-Fernando's Sunburn. Subtly loaded with her point-of-view that some would say still rings true until today, it is a commentary that discusses the Filipino vs. Filipino, also known as crab mentality, as well as the Filipino vs. global world, and the Filipino wanting so desperately to fit in with its international counterparts in spite of the terrible treatment it receives from world, also known as colonial mentality.

It is not explicitly mentioned in the text that the characters were pulling one another down. It was neither intentional nor planned for Noli and the narrator to throw Noli under the bus. One may argue that Noli had dug his own grave and he probably deserved what he had coming to him. However, the fact that Noli and the narrator were watching his downfall without ever trying to actively reach out speaks of crab mentality to its core. In fact, the way the narrator described Magnum, as someone they were clearly ashamed of, is questionable in itself.

It is interesting to note that crab mentality is a clear opposite to what should ring true in establishing Filipino identity: bayanihan. The lack of this Filipino trait was so apparent in the text that the reader, especially a Filipino reader will question the voice of the narrator, in that the narrator also had some biases that were neither explicitly revealed nor discoverable.

Another theme, colonial mentality, shown in Sunburn was an idea more apparent than that of crab mentality. Noli was the character that most exemplified colonial mentality, as he was the one who had been there the longest, and had the most expressed pride that he was indistinguishable from other Americans in his manner of speaking and clothing style. He was also the character that was most upset at Magnum for poorly projecting what Filipinos were like in the fear of being ostracized by the Americans. It is in this we see a clear paradox, wherein the Filipino is so desperate to become an American, even though Americans had been their oppressors just a few years earlier.

Magnum also had his own brand and version of colonial mentality. His personality was such that he wanted the affirmation and the approval from the foreigners. His brand of colonial mentality was that of "propagandizing the Philippines", in that he wanted acceptance from the foreigners but not because he was able to rise above himself, but because of his undeniable, unmistakable Filipino persona.

On a global scale, all the three characters had faced their own versions of racial inequality. While Magnum had retreated back to the Philippines as he realized the difficulties in assimilation in general because of his inherent "Filipino-ness", in both character and persona, Noli and the narrator had first-hand experience with outward racism that, ultimately, forced them to step outside of the delusions they might have had, holding themselves in high regard.

The beauty that lies in this story is in its universality, in that; it still speaks to today's problems that face Filipinos. There is an honesty found in Cordero-Fernando's Sunburn that is still resonant in the present day. The text, with all its flaws and shortcomings, is still a piece that holds. There is a unique corollary that accompanies the text, one that might not be easily seen after the first reading. It is strewn all over the text, and becomes quite glaring: the question of whoNoli, Magnum and the narrator are, who they are as characters, relative to how they see themselves as Filipinos in the context of a global world. And because they are reflections of actual people that exist until today, what does 
that say, then, about the Filipino identity of today? While that should be left for an entirely different discourse, it is a question that is latently thrown to the reader. There is a nagging consciousness that is awakened, that asks readers and begs this question, which is what makes Gilda Cordero-Fernando's Sunburn truly compelling work.

\section{REFERENCES}

Cordero-Fernando, Gilda. "Sunburn." An Anthology of Carlos Palanca Memorial Awards Winners, English Division. Quezon City: Bustamante Press Inc, 1976. Print.

This article is is licensed under a Creative Commons AttributionNonCommercial 4.0 International License. Attribution-NonCommercial (CC BYNC) license lets others remix, tweak, and build upon work non-commercially, and although the new works must also acknowledge \& be non-commercial.

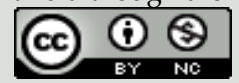

How to Cite: Ledesma MR. 2015. Being Brown: The Inconvenient Truth Asian Journal of Humanity, Art and Literature, 3, 15-22. 


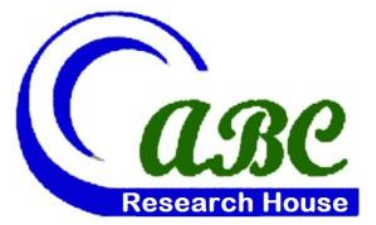

- Off Pantai Dalam, Kuala Lampur, Malaysia

- Road \# 4, Shyamoli, Dhaka-1207, Bangladesh

3900 Woodhue Place, Alexandria, VA 22309, USA

http://journals.abc.us.org/ / www.abcjournals.net

Asian Business Consortium (ABC) is a multi-disciplinary research, training, publishing, digital library supporting and service house. Though founded in 2010 as the Business and Computing organization of Asia, it was reconstituted as the ABC in 2011. It has been working for creating and nurturing talents in USA, Malaysia and Bangladesh since its inception. The objectives of consortium are solely centered round the welfare and humane attitude of the founders who enthusiastically took up this noble cause and materialized it with a view to promote research and educational activities for the encouragement of scholars to develop their knowledge, to publish their analysis oriented scientific researches in international Journals, books, the task of organizing workshops, seminars, conferences, training, personality development programs and allied services.

In addition to research activities, $\mathrm{ABC}$ provides a good number of scholarships to the poor and meritorious students at various levels of education throughout the world. It plays an important role in the field of research by funding research projects and publishing the research papers. This consortium will unquestionably become the mouth-piece of the dark horses and unacknowledged scholar whose endowed and commendable contributions shall be provided an outlet keeping in mind the greater good of the larger society of the world.

$A B C$ runs the following international referred journals for creating a platform to share the thoughts of professionals, scholars and academicians throughout the world.

\section{ABC Publications (ABC Journals)}

- Asian Accounting and Auditing Advancement (4A Journal)

- Asian Business Review (ABR)

- Asian Journal of Applied Sciences and Engineering (AJASE)

- Global Disclosure of Economics and Business (GDEB)

- $\mathrm{ABC}$ Journal of Advanced Research (ABC-JAR)

- International Journal of Reciprocal Symmetry and Theoretical Physics (IJRSTP)

- American Journal of Trade and Policy (AJTP)

- Asian Journal of Humanity, Art and Literature (AJHAL)

- Malaysian Journal of Medical and Biological Research (MJMBR)

- Asia Pacific Journal of Energy and Environment (APJEE)

- $\quad$ Engineering International (EI)

- $\quad$ ABC Research Alert (Online)

Each journal home page provides specific information for potential authors and subscribers. Open access policy, the quick review process, rich editorial boards and quality publications have already made $A B C$ Journals unique. ABC Journals are published under the direct supervisions of renowned academicians of the world.

Collaboration in Conference: $\mathrm{ABC}$ considers high-quality conference papers for publication. Please contact us for detailed information.

Collaboration in Publishing: If you like to start writing a book, propose a new journal or advertise in $\mathrm{ABC}$ journals, please feel free to contact us. 